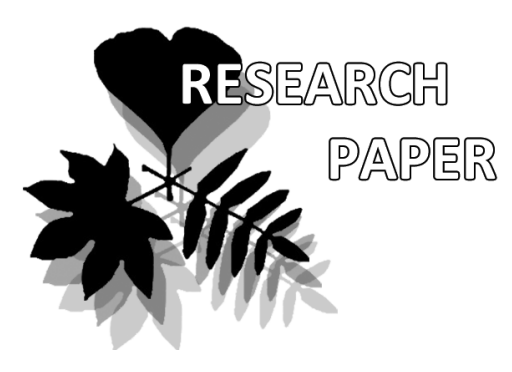

\title{
High frequency in vitro regeneration system for conservation of Barleria prionitis L., a threatened medicinal shrub
}

\author{
Vineet Soni1*, Rakesh Kumari ${ }^{2}$, P.L. Swarnkar ${ }^{3}$
}

Vineet Soni ${ }^{1 *}$

e-mail: vineetsonijnu@gmail.com

Rakesh Kumari $^{2}$

P.L. Swarnkar ${ }^{3}$

${ }^{1}$ Department of Botany, Mohanlal Sukhadia University, Udaipur-313001, Rajasthan, India

${ }^{2}$ School of Life Science, Jaipur National University, Jaipur-302015, Rajasthan, India

${ }^{3}$ Department of Botany, University of Rajasthan, Jaipur-302004, Rajasthan, India

* corresponding author

Manuscript received: 03.11 .2016 Review completed: 05.04.2017 Accepted for publication: 05.05.2017 Published online: 30.06.2017

\begin{abstract}
A B S T R A C T
A rapid and efficient plant propagation system through nodal and embryo cultures was developed for conservation of threatened shrub Barleria prionitis. Nodal explants exhibited high frequency shoot proliferation on Murashige and Skoog (MS) medium supplemented with $1.0 \mathrm{mg} \mathrm{l}^{-1}$ 6-benzylaminopurine (BA) and $0.5 \mathrm{mg} \mathrm{l}^{-1}$ thidiazuron (TDZ). Microshoots were best rooted on half-strength MS fortified with $0.5 \mathrm{mg} \mathrm{l}^{-1}$ indole-3-butyric acid (IBA). Maximum conversion $(63.6 \%)$ of zygotic embryos into well rooted plantlets was achieved on halfstrength MS supplemented with $20 \mathrm{mg} \mathrm{l}^{-1}$ sucrose, devoid of any growth regulator S. Plantlets with high PSII photochemical efficiency ( $\mathrm{Fv} / \mathrm{Fm} \geq 0.8)$ were successfully shifted to natural conditions. The overall survival rate during acclimatization from in vitro growth to field transfer was $81 \%$. The developed micropropagation protocol can be successfully used for large-scale multiplication and conservation this high value medicinal plant species.
\end{abstract}

K e y w o r d s : micropropagation; embryo culture; in vitro rhizogenesis; chlorophyll fluorescence; acclimatization

\section{P E 3 Ю M E}

Сони В., Кумари Р., Шварнкар П.А. Система интенсивной регенерации in vitro А^я coхранения Barleria prionitis L., реАкого Аекарственного кустарника. Разработана быстрая и эффективная система размножения растений через меристемные и эмбриональные культуры Аля сохранения угрожаемого кустарникового вида Barleria prionitis. Меристемные эксплантаты Аемонстрировали интенсивную пролиферацию побегов на среде Murashige и Skoog (MS), Аополненную 1,0 мг/ 6-бензиламинопурином (BA) и 0,5 мг / м тидиазуроном (TDZ). Микропобеги кучше всего укоренялись на MS,

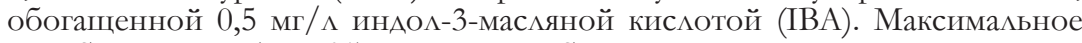
преобразование $(63,6$ \%) зиготных эмбрионов в укоренившиеся растения было Аостигнуто на MS, Аополненной 20 мг/ сахарозы, Аишенной какоголибо регулятора роста S. Растеньица с высокой фотохимической эффективностью PSII (Fv / Fm $\geq 0,8)$ были успешно перенесены в естественную среду. Общая выживаемость при акклиматизации от роста in vitro до переноса в естественную среду состав яла 81 \%. Разработанный протокол микроразмножения может быть успешно использован Аля крупномасштабного размножения и сохранения этих высокоценных лекарственных растений.

К $\boldsymbol{\Lambda}$ ю че в ы е с $\mathbf{~ о ~ в ~ а : ~ м и к р о р а з м н о ж е н и е , ~ к у л ь т у р а ~ э м б р и о н о в , ~ к о р н е о б р а з о в а - ~}$ ние in vitro, флуоресценция хлорофилла, акклиматизация
Barleria prionitis L., (Acanthaceae), an annual medicinal shrub of arid and semiarid regions of Africa and Asia, is used in the Indian and Chinese traditional system of medicine since prehistoric time. It have shown antiviral (Chen et al. 1998), anti-spermatogenic (Verma et al. 2005), hepatoprotective (Singh et al. 2005), antidiabetic (Dheer \& Bhatnagar 2010), anti-nociceptive (Jaiswal et al. 2010), anti-inflammatory (Khadse \& Kakde 2011), antifungal (Amoo et al. 2011), diuretic (Musale et al. 2011), antibacterial (Diwan \& Gadhikar 2012), antidepresent (Gangophadhyay et al. 2012), immunomodulatory (Ghule \& Yeole 2012), anti-arthritic (Choudhary et al. 2014) and antifertility (Singh \&
Gupta 2016) activities. The plant is especially well known for treating bleeding gums and toothache (Gupta et al. 2016). Unfortunately, the wild population of this plant is now threatened into extinction because of over exploitation and lack of organized cultivation (Walter \& Gillett 1998). Conventionally $B$. prionitis is propagated mainly through the seeds and stem cuttings. However, germination of seeds is poor and propagation through stem cuttings solely relies on season for multiplication, which makes it an inefficient way for the conservation of this medicinally important plant. So this plant species requires immediate attention for its protection, large scale systematic cultivation and conservation. 
Plant tissue culture is an alternative to the conventional methods of propagation with the objective of enhancing the rate of multiplication and conserving the threatened medicinal plant species. The large scale production of micropropagated plantlets is often limited by poor survival when plantlets are transferred in ex vitro conditions. The high exogenous sucrose content in the medium has been shown to suppress photosynthetic gene expression, reduce chlorophyll content, reduce Calvin cycle enzymes, as well as reduce Rubisco activity and Rubisco concentration, leading to low photosynthetic rates (Van Huylenbroeck \& Debergh 1996, Sinha et al. 2002, Fuentes et al. 2005). The benefit of any micropropagation system can, however, only be fully realized by the successful transfer of plantlets from tissueculture vessels to the ambient conditions found ex vitro.

The establishment of tissue culture protocol will be an important action for multiplication and germplasm conservation of $B$. prionitis. Thus, the objective of this work was to develop a highly efficient in vitro regeneration protocol of B. prionitis through nodal and embryo cultures. The present work also evaluated effects of altering medium strength and sucrose concentration on in vitro zygotic embryo germination. In addition, assessment of photosynthetic performance of hardened plants by chlorophyll a fluorescence analysis was carried out to ensure their the high survival rate in natural conditions.

\section{MATERIAL AND METHODS}

\section{Plant material and surface sterilization}

Nodal explants and seeds were collected from healthy plants of B. prionitis growing in the Jhanana Nursery, Jaipur (India). The excised nodal explants were washed thoroughly under running tap water for $30 \mathrm{~min}$ to eliminate dust particles and then with $5 \%$ teepol for 8-10 min and rinsed several times in sterile distilled water. Then, the explants were treated with an antifungal agent (Bavistin) for 1 hour and the again rinsed three times with sterile distilled water. Thereafter, the explants were surface sterilized under a laminar flow chamber with aqueous solution of $0.1 \% \mathrm{HgCl}_{2}$ for 2 min and finally washed with sterile distilled water for 2-3 times. Similarly, the seeds were surface disinfected and zygotic embryos were aseptically excised by cracking the seed coats.

\section{Culture media and growth conditions}

The sterilized nodal explants were cultured on MS Medium (Murashige \& Skoog 1962) supplemented with $3 \%$ (w/v) sucrose and various combinations/concentrations of plant growth regulators. The zygotic embryos were inoculated at full or half strength MS supplemented with various concentrations sucrose $\left(10,20\right.$ and $\left.30 \mathrm{~g} \mathrm{l}^{-1}\right)$. The $\mathrm{pH}$ of the media was adjusted 5.8 before autoclaving $121^{\circ} \mathrm{C}$ for $15 \mathrm{~min}$. All the cultures were maintained at $25 \pm 2^{\circ} \mathrm{C}$ and $65-70 \%$ relative humidity with photoperiod of 16 -h using a photosynthetic photon flux density (PPFD) of $40 \mathrm{mmol} \mathrm{m} \mathrm{s}^{-1}$ provided by cool white fluorescent tubes (Philips, India).

\section{In vitro rhizogenesis and hardening}

Elongated shoots with 2-3 pairs of healthy leaves were excised and transferred to rooting medium. The shoots were cultured on MS supplemented with various auxins viz. IBA,
IAA and NAA. Well rooted plantlets, derived from both nodal and embryo cultures, were gently washed in sterile water and transferred to plastic cups $(10 \times 8 \mathrm{~cm})$ containing sterilized mixture of sterile soil, sand and coco peat $(1: 2: 1)$. The plantlets covered in transparent polyethylene bags were kept for 4 weeks in growth chamber at $25 \pm 2^{\circ} \mathrm{C}$ with $16 \mathrm{~h}$ photoperiod and $40 \mathrm{mmol} \mathrm{m} \mathrm{m}^{-1}$ of irradiation. The plantlets were irrigated with tap water. The irrigation schedule and volume of water was calibrated to keep the pot mixture saturated and prevent flooding. The hardened plants were subsequently transferred to large pots containing normal garden soil and were maintained in an open greenhouse without environmental conditioning for 4 weeks.

\section{Measurement of Fv /Fm and acclimatization}

Photosynthetic screening during hardening process can help to improve the performance and survival of micropropagated plants. Thus, maximum quantum yield of primary photochemistry $\varphi \mathrm{P}_{0}=\mathrm{TR}_{0} / \mathrm{ABS}=\left(\mathrm{Fm}-\mathrm{F}_{0}\right) / \mathrm{Fm}=\mathrm{Fv} / \mathrm{Fm}$ (where TR and ABS denote the trapped and absorbed excitation energy fluxes) of plantlets growing under growth chamber and green house conditions was regularly measured using a Plant Efficiency Analyser, PEA (Hansatech Instruments, Kings Lynn, Norfolk, U.K.) according to Heber et al. (2011). The leaf samples were dark adapted for 2 hours before the fluorescence measurements. Plantlets having high PSII photochemical efficiency ( $\mathrm{Fv} / \mathrm{Fm} \geq 0.8)$ were shifted to natural conditions. The survival rate of plantlets was recorded after 1 month of transfer to natural conditions.

\section{Experimental design and statistical analysis}

All the experiments were conducted with a minimum of 30 replicates per treatment and each experiment was repeated thrice. The data were analyzed statistically by one-way analysis of variance (ANOVA) followed by Tukey's test at $\mathrm{P}=5 \%$ using SPSS software version 17.0 (SPSS Inc., Chicago, IL, USA) and data represented as mean \pm standard error (SE).

\section{RESULTS AND DISCUSSION}

\section{In vitro establishment and multiplication}

Development of single unhealthy (yellowish) shoot followed by the formation of green nodular callus at the basal part of nodal explants was observed at $0.5 \mathrm{mg} \mathrm{l}^{-1} \mathrm{BA}$ after 9 days of culture (Fig. 1 A, B). TDZ alone in different concentrations $\left(0.5,1.0,2.5 \mathrm{mg} \mathrm{l}^{-1}\right)$ failed to induce high frequency shoot bud proliferation in vitro. Development of healthy shoot buds was recorded when low concentration of TDZ $\left(0.5 \mathrm{mg} \mathrm{l}^{-1}\right)$ was incorporated in MS along with BA (Table 1). The best response in terms of explants plant response $(\%)$ and mean shoot length was observed on MS supplemented with $1.0 \mathrm{mg} \mathrm{l}^{-1} \mathrm{BA}$ and $0.5 \mathrm{mg} \mathrm{l}^{-1} \mathrm{TDZ}$ (Fig. $1 \mathrm{C}$ ).

Frequency of shoot induction was drastically decreased with increasing concentration of BAP, either singly or in combination with TDZ $\left(0.5 \mathrm{mg} \mathrm{l}^{-1}\right)$. An inhibitory effect of higher concentrations of $\mathrm{BA}$ on in vitro shoot proliferation has also been reported earlier in Albizia chinensis (Osbeck) Merr. (Sinha et al. 2000), Pterocarpus marsupium (Swynn. ex Baker f.) Swynn. ex Steedman (Anis et al. 2005), Arachis bypogaea L. (Banerjee et al. 2007), Doritis pulcherrima Lindl. (Mondal et al. 2013) and Salvia splendens Sellow ex Schult. 

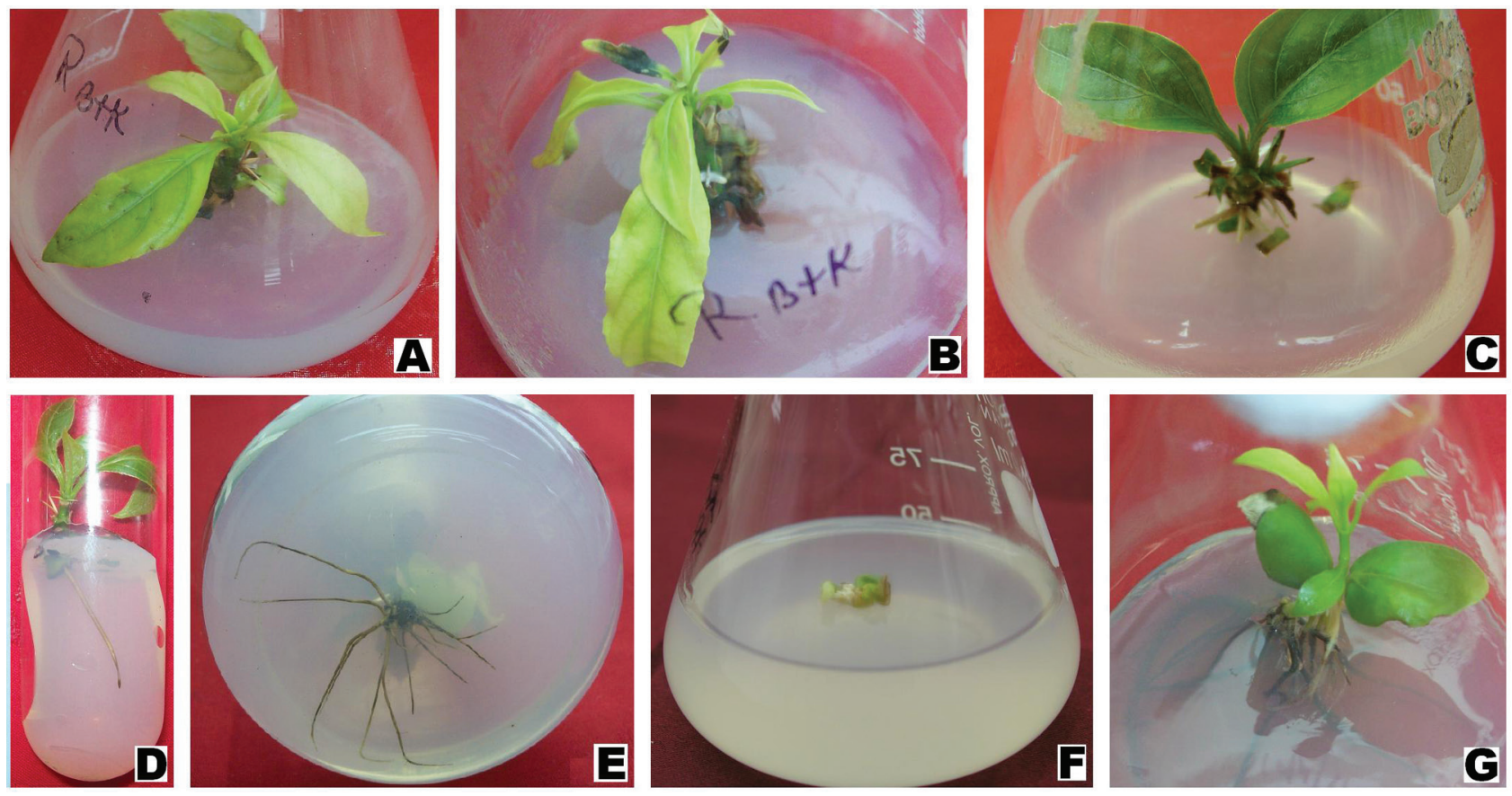

Figure 1 In vitro propagation of B. prionitis. A, B - shoot induction from nodal explant on $\mathrm{MS}$ with $0.5 \mathrm{mg} \mathrm{l}^{-1} \mathrm{BA}$, and (C) $1.0 \mathrm{mg}^{-1} \mathrm{BA}$ and $0.5 \mathrm{mg} \mathrm{l}^{-1} \mathrm{TDZ}$, 4-week-old culture. $\mathrm{D}$ - in vitro rhizogenesis on half-strength $\mathrm{MS}$ with $2.0 \mathrm{mg} \mathrm{l}^{-1} \mathrm{IBA}$, and (E) $0.05 \mathrm{mg} \mathrm{l}^{-1} \mathrm{IBA}$, 4-week-old culture. $\mathrm{F}$ - in vitro germination of zygotic embryo, and $\mathrm{G}$ - well rooted plantlet developed from zygotic embryo culture on half-strength MS with $20 \mathrm{mg} \mathrm{l}^{-1}$ sucrose.

(Sharma et al. 2014). Other plant growth regulators, singly or in combinations could not initiate any significant morphogenetic response in nodal explants of B. prionitis.

\section{In vitro rhizogenesis}

Overall, MS of half-strength proved better for root induction as compared to full strength MS whether with or without IBA of any concentration (Table 2). The rooting characters like percentage of shoots producing roots, mean no. of root/shoot and mean root length $(\mathrm{cm})$ have been influenced by the MS strength and IBA concentration. Halfstrength MS along with higher concentration of IBA could induce rhizogenesis in vitro at low frequency (Fig. I D). Medium having half-strength MS supplemented with $0.5 \mathrm{mg}$ $1^{-1}$ IBA recorded to be the best root inducing medium for microshoots developed from nodal explants of B. prionitis (Fig 1 E). Similarly, the effect of IBA on root induction has been reported in many plant species, i.e. Plectranthus bourneae Gamble (Thaniarasu et al. 2015), Passiflora foetida L. (Shekhawat et al. 2015), Morinda coreia Buch.-Ham. (Shekhawat et al. 2015), Ceropegia evansii McCann (Chavan et al. 2015).

\section{Embryo germination}

Carbohydrates play an important role in the maintenance of an adequate osmotic balance in the growth medium as well as in the promotion of embryo growth. Sucrose has been widely used as an energy source because explants cultivated in vitro are heterotrophic and depend on external energy and carbon sources (Hu \& Ferreira 1998). Sucrose concentration is important in early stages of zygotic embryo germination as young embryos require a complex medium for growth and maturation. In present study, a highly significant effect of altering medium strength and sucrose concentration was observed on germination of zygotic embryos of B. prionitis (Table 3). Considering all of the variables examined (percent germination, mean plant height and mean no. of root/plant), half-strength MS fortified with $20 \mathrm{mg} \mathrm{l}^{-1}$ sucrose, devoid of any growth regulators, was the best culture medium for obtaining in vitro differentiation of zygotic embryos into plantlets (Fig 1 F, G). Higher concentration of sucrose $\left(30,40 \mathrm{mg} \mathrm{l}^{-1}\right)$ showed an inhibitory effect on embryo germination.

\section{Hardening and acclimatization}

The increased use and efficiency of micropropagation is still restricted by the high percentage of plants which are lost or damaged when transferred to ex vitro conditions (Pospísilová et al. 1999). It is due to a poor photosynthetic capacity of in vitro-cultured plantlets, apparently caused by insufficient inflow of carbon dioxide and the sucrose added to growth medium causing negative feedback for photosynthesis. Therefore, screening photosynthetic/autotrophic potential of hardened plants is essential to optimize hardening duration to ensure their high survival rate in ex vitro conditions. In the present investigations, plantlets regenerated in vitro were successfully acclimatized in the growth chamber (88\% survival) and then in the greenhouse (92\% survival). The $\mathrm{Fv} / \mathrm{Fm}$ value, a sensitive and early indicator of photo-inhibition and changes in photochemical efficiency, increased throughout hardening process, providing evidence for increasing photosynthetic performance. In vitro developed plants of B. prionitis significantly achieved Fv / Fm value from 2.34 to 8.06 within 6 weeks of hardening process in growth chamber and green house conditions (Fig 2 A). 
Table 1. Influence of BA and TDZ on shoot proliferation and regeneration after 4 weeks of culture of nodal explants of B. prionitis. Values represent the mean of 30 replicates \pm standard error $(\mathrm{SE})$.

\begin{tabular}{c|c|c|c}
\hline \multicolumn{2}{c|}{$\begin{array}{c}\text { Plant growth } \\
\left.\text { regulators (mg 1 } \mathbf{~}^{-1}\right)\end{array}$} & Explant response (\%) & Mean shoot length (cm) \\
\cline { 1 - 2 } BA & TDZ & & \\
\hline 0.5 & 0.0 & $23.0 \pm 2.1$ & $0.3 \pm 0.03$ \\
1.0 & 0.0 & $17.7 \pm 3.3$ & $0.9 \pm 0.04$ \\
2.5 & 0.0 & $12.6 \pm 2.2$ & $0.6 \pm 0.02$ \\
5.0 & 0.0 & $9.6 \pm 1.7$ & $0.4 \pm 0.01$ \\
0.0 & 0.5 & $21.9 \pm 2.1$ & $0.5 \pm 0.06$ \\
0.0 & 1.0 & $16.6 \pm 2.0$ & $0.6 \pm 0.07$ \\
0.0 & 2.5 & $12.4 \pm 2.3$ & $0.7 \pm 0.10$ \\
0.5 & 0.5 & $56.6 \pm 2.7$ & $0.9 \pm 0.04$ \\
1.0 & 0.5 & $87.2 \pm 3.6$ & $2.5 \pm 0.10$ \\
2.5 & 0.5 & $38.4 \pm 3.1$ & $0.8 \pm 0.06$ \\
5.0 & 0.5 & $18.5 \pm 2.0$ & $0.7 \pm 0.04$ \\
0.5 & 1.0 & $22.8 \pm 2.9$ & $0.9 \pm 0.07$ \\
1.0 & 1.0 & $9.7 \pm 2.2$ & $0.6 \pm 0.04$ \\
0.5 & 2.5 & $14.9 \pm 3.3$ & $0.6 \pm 0.01$ \\
1.0 & 2.5 & $5.4 \pm 2.1$ & $0.4 \pm 0.10$ \\
\hline
\end{tabular}

Table 2. Influence of IBA on in vitro rhizogenesis in B. prionitis after 4 weeks of culture. Values represent the mean of 30 replicates \pm standard error (SE).

\begin{tabular}{l|ccc}
\hline Media Combinations & $\begin{array}{c}\% \\
\text { Rooting }\end{array}$ & $\begin{array}{c}\text { Mean no. } \\
\text { of root/ } \\
\text { shoot }\end{array}$ & $\begin{array}{c}\text { Mean root } \\
\text { length }(\mathbf{c m})\end{array}$ \\
\hline MS full strength & - & - & - \\
MS full strength $+0.5 \mathrm{mg} \mathrm{l}^{-1} \mathrm{IBA}$ & $22 \pm 2.2$ & $1.14 \pm 0.3$ & $0.77 \pm 0.2$ \\
MS full strength $+1.0 \mathrm{mg} \mathrm{l}^{-1} \mathrm{IBA}$ & $34 \pm 4.1$ & $1.79 \pm 0.5$ & $2.26 \pm 0.7$ \\
MS full strength $+2.0 \mathrm{mg} \mathrm{l}^{-1} \mathrm{IBA}$ & $36 \pm 4.4$ & $2.74 \pm 0.4$ & $2.29 \pm 0.4$ \\
MS half strength & $56 \pm 2.6$ & $1.58 \pm 0.3$ & $2.61 \pm 0.8$ \\
MS half strength $+0.5 \mathrm{mg} \mathrm{l}^{-1} \mathrm{IBA}$ & $94 \pm 6.8$ & $6.50 \pm 1.1$ & $3.78 \pm 0.3$ \\
MS half strength $+1.0 \mathrm{mg} \mathrm{l}^{-1} \mathrm{IBA}$ & $64 \pm 4.3$ & $8.50 \pm 1.4$ & $4.13 \pm 0.5$ \\
MS half strength $+2.0 \mathrm{mg} \mathrm{l}^{-1} \mathrm{IBA}$ & $53 \pm 6.6$ & $2.66 \pm 0.5$ & $1.11 \pm 0.4$ \\
\hline
\end{tabular}

Table 3. Influence of medium strength and sucrose concentration on embryo germination. Values represent the mean of 30 replicates \pm standard error (SE).

\begin{tabular}{l|c|c|c|c}
\hline $\begin{array}{l}\text { Medium } \\
\text { strength }\end{array}$ & $\begin{array}{c}\text { Sucrose } \\
\left(\mathbf{m g ~}^{-1}\right)\end{array}$ & $\begin{array}{c}\text { Germination } \\
\mathbf{( \% )}\end{array}$ & $\begin{array}{c}\text { Mean plant } \\
\text { Height }(\mathbf{c m})\end{array}$ & $\begin{array}{c}\text { Mean no. of } \\
\text { root/plant }\end{array}$ \\
\hline Half & 0 & $26 \pm 3.1$ & $1.5 \pm 0.2$ & $1.5 \pm 0.6$ \\
& 10 & $56 \pm 4.5$ & $2.3 \pm 0.5$ & $2.3 \pm 0.7$ \\
& 20 & $94 \pm 3.4$ & $3.6 \pm 0.7$ & $8.5 \pm 1.1$ \\
& 30 & $81 \pm 5.1$ & $1.6 \pm 0.3$ & $4.4 \pm 0.5$ \\
Full & 40 & $65 \pm 4.2$ & $1.2 \pm 0.3$ & $4.2 \pm 0.3$ \\
& 0 & $12 \pm 2.1$ & $1.3 \pm 0.3$ & $1.0 \pm 0.4$ \\
& 10 & $18 \pm 2.4$ & $1.2 \pm 0.3$ & $1.5 \pm 0.2$ \\
& 20 & $38 \pm 1.8$ & $2.3 \pm 0.4$ & $2.0 \pm 0.7$ \\
& 30 & $26 \pm 3.2$ & $1.5 \pm 0.2$ & $2.1 \pm 0.4$ \\
& 40 & $9 \pm 2.1$ & $1.3 \pm 0.5$ & $1.4 \pm 0.3$ \\
\hline
\end{tabular}

Fully hardened plants of about $8 \mathrm{~cm}$ having high PSII photochemical efficiency ( Fv/ $F m \geq 0.8)$ were shifted to plastic bags containing garden soil and maintained under natural conditions with $100 \%$ survival rate (Fig. 2 B). The developed in vitro protocol can be useful for the conservation and mass propagation of this threatened medicinal plant species. Photosynthetic screening of in vitro raised plantlets, as described in present study, could also be used for the acclimatization of other threatened species with high survival rate and their eventual establishment in the field.

\section{ACKNOWLEDGEMENTS}

The authors are grateful to the Jaipur $\mathrm{Na}$ tional University for providing infrastructure and financial support for this research.

\section{LITERATURE CITED}

Amoo, S.O., A.R. Ndhlala, J.F. Finnie \& J. Van Staden 2011. Antifungal, acetylcholinesterase inhibition, antioxidant and phytochemical properties of three Barleria species. South African Journal of Botany 77:435-45.

Anis, M., M.K. Husain \& A. Shahzad 2005. In vitro plantlet regeneration of Pterocarpus marsupium Roxb., an endangered leguminous tree. Current Science 88:861-863.

Banerjee, P., S. Maity, S.S. Maiti \& N. Banerjee 2007. Influence of genotype on in vitro multiplication potential of Arachis bypogaea L. Acta Botanica Croatica 66:15-23.

Chavan, J.J., N.B. Gaikwad, P.R. Kshirsagar, S.D. Umdale, K.V. Bhat, G.B. Dixit \& S.R. Yadav 2015. Highly efficient in vitro proliferation and genetic stability analysis of micropropagated Ceropegia evansii by RAPD and ISSR markers: A critically endangered plant of Western Ghats. Plant Biosystems 149:442-450.

Chen, J.L., P. Blanc, C.A. Stoddart, M. Bogan, E.J. Rozhon, N. Parkinson, Z. Ye et al. 1998. New iridoids from the medicinal plant Barleria prionitis with potent activity against respiratory syncytial virus. Journal of Natural Products 61: 1295-7.

Choudhary, M., V. Kumar, P.K. Gupta \& S. Singh 2014. Anti-arthritic activity of Barleria prionitis Linn. leaves in acute and chronic models in Sprague Dawley rats. Bulletin of Faculty

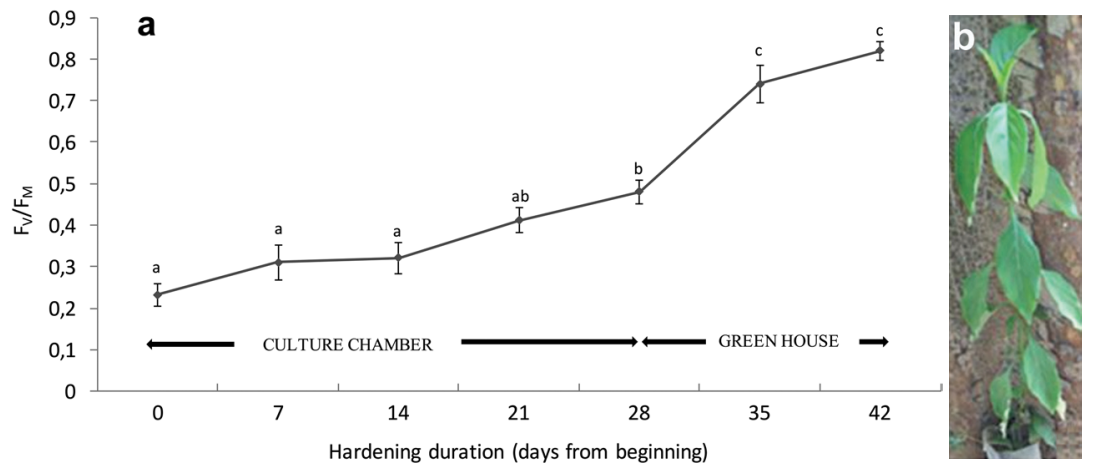

Figure 2. a - Fv/Fm (TR0/ABS) values of in vitro raised plantlets during hardening process in growth chamber and green house (Bars represent the mean of 30 replicates \pm standard error (SE). Mean values indicated by the same superscript are not significantly different $(\mathrm{P}=$ $5 \%$; Tukey's test). $\mathrm{b}$ - acclimatized plantlet in field, 8 months after transfer 
of Pharmacy, Cairo University 52:199-209.

Dheer, R. \& P. Bhatnagar 2010. A study of the antidiabetic activity of Barleria prionitis Linn. Indian Journal of Pharmacology 42:70-73.

Diwan, P.D. \& Y.A. Gadhikar 2012. Assessment of phytochemical composition and antibacterial activity of different extracts of Barleria prionitis leaves against oral microflora to improve dental hygiene. Asian Journal of Pharmaceutical Sciences 5:182-184.

Fuentes, G., C. Talavera, C. Oropeza, Y. Desjardins \& J.M. Santamaria 2005. Exogenous sucrose can decrease in vitro photosynthesis but improve field survival and growth of coconut (Cocos nucifera L.) in vitro plantlets. In vitro cellular \& developmental biology. Plant 4: 69-76.

Gangophadhyay, A., J. Malakar, A. Gosh, J. Deb, S. Dey, S. Datta \& P.K .Datta 2012. The central nervous system activity of Barleria prionitis L. on the locomotor activity of swiss albino mice using actophotometer. International Journal of Pharmaceutical and Biological Archiver 3: 403-405.

Ghule, B.V. \& P.G. Yeole 2012. In vitro and in vivo immunomodulatory activities of iridoids fraction from Barleria prionitis Linn. Journal of Ethnopharmacology 141:424-431.

Gupta, D., R.K. Gupta, A. Jain, S. Bindhumadhav, S. Sangeeta, P. Garg, S. Chaturvedi et al. 2016. Assessment of effectiveness of Barleria prionitis on oral health. Pharmacognosy Research 8:169-172.

Heber, U., V. Soni \& R.J. Strasser 2011. Photoprotection of reaction centers: thermal dissipation of absorbed light energy vs charge separation in lichens. Physiologia Plantarum 142:65-78.

Hu, C.Y. \& A.G. Ferreira. 1998. Cultura de embriões. In: Cultura de tecidos e transformacão genética de plantas, v. 1., (A.C. Torres, L.S. Caldas \& J.A. Buso, eds), pp. 371-393. Brasília, DF, Embrapa-SPI/EmbrapaCNPH.

Khadse, C.D. \& R.B. Kakde 2011. Anti-inflammatory activity of aqueous extract fractions of Barleria prionitis L. roots. Asian Journal of Plant Science Research 1: 63-68.

Mondal, T., S. Aditya, N. Banerjee 2013. In vitro axillary shoot regeneration and direct protocorm-like body induction from axenic shoot tips of Doritis pulcherrima Lindl. Plant Tissue Culture and Biotechnology 23:251-261.

Murashige, T. \& F. Skoog 1962. A revised medium for rapid growth and bioassays with tobacco tissue cultures. Physiologia Plantarum 15:473-497.

Musale, S.B., V.A. Jagtap, M.S. Patil, K. Chittam \& R. Wagh 2011. Diuretic activity of Barleria prionitis Linn. flower extract. International Journal of Drug Discovery and Herbal Research 1:20-21.
Pospíšilová, J., I. Tichá, P. Kadleček, D. Haisel \& Š. Plzáková 1999. Acclimatization of micropropagated plants to ex vitro conditions. Biologia Plantarum 42:481-497.

Sharma, S., A. Shahzad, J. Kumar \& M. Anis 2014. In vitro propagation and synseed production of scarlet salvia (Salvia splendens). Rendiconti Lincei 25:359-368.

Shekhawat, M.S., M. Manokari \& C.P. Ravindran 2015. An improved micropropagation protocol by ex vitro rooting of Passiflora edulis Sims. f. flavicarpa Deg. through nodal segment culture. Scientifica (Cairo) 2015:1-8.

Shekhawat, M.S., N. Kannan \& M. Manokari 2015. In vitro propagation of traditional medicinal and dye yielding plant Morinda coreia Buch.-Ham. South African Journal of Botany 100:43-50.

Singh, B., B.K. Chandan, A. Prabhakar, S.C. Taneja, J. Singh \& G.N. Qazi 2005. Chemistry and hepatoprotective activity of an active fraction from Barleria prionitis Linn. in experimental animals. Phytotherapy Research 19:391-404.

Singh, K. \& R.S. Gupta 2016. Antifertility activity of $\beta$-sitosterol isolated from Barleria prionitis L. roots in male albino rats. International Journal of Pharmacy and Pharmaceutical Sciences 8:88-96.

Sinha, A., M. Hofmann, U. Römer, E.L. Köckenberger, T. Roitsch 2002. Metabolizable and non-metabolizable sugars activate different signal transduction pathways in tomato. Plant Physiology 128:1480-1489.

Sinha, R.K., K. Majumdar \& S. Sinha 2000. In vitro differentiation and plant regeneration of Albizia chinensis (OBS.) MERR. In Vitro Cellular \& Developmental Biology - Plant 36:370-373.

Thaniarasu, R., T. Senthil Kumar \& M.V. Rao 2015. In vitro propagation of Plectranthus bourneae Gamble an endemic red listed plant. Plant Tissue Culture and Biotechnology 25:273-284.

Van Huylenbroeck, J.M. \& P.C. Debergh 1996. Impact of sugar concentration in vitro on photosynthesis and carbon metabolism during ex vitro acclimatization of Spathiphyllum plantlets. Physiologia Plantarum 96:298-304.

Verma, P.K, A. Sharma, S.C Joshi, R.S. Gupta \& V.P. Dixit 2005. Effect of isolated fractions of Barleria prionitis root methanolic extract on reproductive function of male rats: preliminary study. Fitoterapia 76:428-432.

Walter, K.S. \& H.J.Gillett 1998. 1997 IUCN Red List of Threatened Plants, IUCN, Gland, Switzerland and Cambridge, UK. 